\title{
Noblewomen's Dowries in the Grand Duchy of Lithuania in the Sixteenth - Seventeenth Centuries
}

\author{
BY
}

NATALLIA SLIŽ*

Although such aspects of marriage in the context of social history as the term marriage, marriage relations, dowry and others have been touched upon in scholarship (Goody 1983, Sabean 1992, Strasser 2004, Kompiola 2011, Johnson and Sabean 2011), noble marriage in the Grand Duchy of Lithuania (GDL) in the sixteenth - seventeenth centuries remain a scantily explored branch of research in Belarusian and foreign historiography.

A number of studies present noblewomen's dowries in the context of the development of family law and private documents ${ }^{1}$, but there is no separate research devoted to the realisation of norms about dowries in legal practice. Moreover, the study of noblewomen's dowries reveals information not only about female property but also about women's status in family and society, and about family relations. Thus the topic's relevance to historiography.

The purpose of this paper is to analyse the process of giving a dowry to a noblewoman in the Grand Duchy of Lithuania in the sixteenth - seventeenth centuries.

The article consists of the following parts. The first part presents the general characteristics of the country, its legal system and some aspects of family law. The second part pays attention to apportionment of a dowry in a noble family. The third part analyses judicial process and conflicts in families where the main point was a dowry. The fourth part is devoted to notification of receiving a dowry, and the

Natallia Sliž, PhD is a historian working at the Hrodna branch of BIP Institute of Law and the author of more than 100 artcles. Her scholarly interests include the history of noble families and marriages, miracle icons, and the history of Hrodna in the sixteenth - seventeenth centuries. miracle icons, and the history of Hrodna in the sixteenth - seventeenth centuries.

1 It is necessary to mention the studies made by Levickyj (1994), Vladimirski-Budanov (1890), Liubavskii (1892, 572-81), Spasovich (1890), Skitstkii (1907), Daniłowicz (1841), Czacki (1861, 1-22), Bardach (1963; 1988; 1989), Taŭstales (2009), Dzierbina (1997), Lazutka and Valikonytė (1976), Valikonytė (1978; 1982; 1997), Andriulis (2003), Ulrich Ernst, Jurgita Kunsmanaitė (2009), Śliž $(2007 ; 2008 ; 2009 ; 2011 ; 2012)$. 
reasons for the appearance of this document. The last part proves that a noblewoman had the right to dispose of a dowry herself, and demonstrates how she was able to release it. The article ends with a number of conclusions.

\section{The Grand Duchy of Lithuania: the Legal System and Family Law}

The Grand Duchy of Lithuania existed from the middle of the thirteenth till the end of the eighteenth centuries. The country was one of the largest in Europe and covered the territory of modern Belarus, Lithuania, Latvia (Daugavpils region), Ukraine (Volhynia, Kyiv, Podillia), Poland (Białystok region), and Russia (Smolensk and Briansk regions). The boundaries changed over time as a result of political and international events (see works about the GDL: Halecki 1958, Frost 1995, 183-22; Friedrich and Pendzich 2009 and Pietkiewicz 1995).

The inhabitants of the GDL included the nobility, petty bourgeoisie, peasantry, and clergy. The nobility played the main role in society because only the representatives of this stratum had the right to take part in making policy and holding official posts. The introduction of Magdeburg law raised the status of towns. Vilna ${ }^{2}$ possessed exclusive status above other towns and its magistrates had the right to join the nobility. Representatives from various strata could be clergy but the main post as a bishop was given only to persons of high estate.

The peasantry consisted of two main groups: state and private. The division of inhabitants influenced the formation of the judicial system in the country. Cases between peasants were heard at the kopny court, and then, if necessary, at the castle court where it was transformed in the hrodski. The Magdeburg court operated in towns under the Magdeburg law. Before the Statute of 1529, the Grand Duke and the Council of Lords (Pany Rada) considered most cases concerning the nobility.

The castle courts and courts of the palatines of Vilna and Troki ${ }^{3}$ began gradually to play a greater role in local society. Experimental zemski courts for the nobility (for example in Hrodna) ${ }^{4}$ were organized in the 1550s. Zemski and hrodski courts based on new principles, appeared after the reforms of 1560. The Tribunal of the GDL, the highest court of appeal, was established in 1581. Assessor court worked under the rule of the Polish King and the Grand Duke. The petty bourgeoisie and the nobility turned to them in complicated cases (Lappo 1911, Liubavskii 1892, Dovnar-Zapol'ski 1901, Šalanda 2009, 35-64; Družčyc 2009, 241-337).

The state language was Old Belarusian or jazyk ruski. Inhabitants used it in all

\footnotetext{
Today Vilnius, Lithuania.

3 Personal and geographical names are used in transliteration from the Old Belarusian language.

4 Today Hrodna, Belarus.
} 
spheres of life. This was natural, because the greater part of the population were rusiny (Ruthenians), had Slavic origins and were Orthodox Christians. State and private documents were in Old Belarusian in the chancellery of the GDL and local courts ${ }^{5}$ which led to the development of the structure of documents. It was a language of record keeping in estates and correspondence. ${ }^{6}$ Its wide usage in state and private spheres promoted the development of terminology in law, economy, military science, everyday life and others. ${ }^{7}$ Translated literature, religious writings and fiction, and Francysk Skaryna's publishing activities all show the elevated position of the language in the sixteenth century. ${ }^{8}$

Old Belarusian culture dominated till the end of the sixteenth century. But the first half of the seventeenth century started the beginning of the influence of Polish culture on the nobility in the GDL. The Counter-Reformation played an active role in these tendencies. It provoked religious and cultural conflicts in society. The nobility changed their religion wholesale and accepted Catholicism in order to keep their power and posts. Little by little the Polish language replaced Old Belarusian, especially in the western regions of the GDL. 'Uneducated' peasants and the bourgeoisie remained native speakers of Old Belarusian, because they did not come under the same strong influence of Catholicism and Polish culture.

We should note that the sixteenth century was an important period for the development of the legal system in the GDL. Three codes of law were published in 1529,1566 , and 1588 , the judicial system and state and private documentation completed its formation in this period. The most prominent role in developing legal culture belonged to the nobility. Its representatives were in the commission of the Statutes, were judges and advocates, and wrote private documents.

Before the acceptance of the Statute of 1529, marriage relations in the GDL were regulated by common law, the land (ahuĺnaziemskija) and provincial (ziemskija) privileges (AJUZ, vol. 2 1848; Zhemantis 1997, 415-25; Lietuvos Metrika, kn. 25, 35-49), and legal practice (Daniłowicz, volume 2, 279; Lazutka and Valikonytė 1976, 84; Kunsmanaitè 2009, 70-71; Picheta 1961, 511-14; Lazutka 1982, 150).

Putting into force the Statute of 1529 (Iablonskis, 1960; von Loewe, 1976;

5 It is proved by numerous editions of the Metrika of the GDL, editions of the zemski and hrodski record books by Vilna commission, original books from different regions: Hrodna, Vilna, Polack, and others. For a list of editions see the website: www.starbel.narod.ru.

6 The most vivid example is a private archive compiled by Ivan Hornostaj, treasurer of GDL. All documents were in Old Belarusian; Archiwum Główne Aktów Dawnych (AGAD); Archiwum Potockich z Radzynia, Sygn. 317.

7 For example, judicial practice and publications of the Statutes of 1529, 1566, and 1588 formed the system of terms in legislation. The names of implements, coats of arms, clothes, and others were known in everyday life. See inventories in Akty Izdavaemye Vilenskoiu Arkheograficheskoio Komissieiu, vol. 14. Inventari Imienii XVI Stoletiia, Vil'na 1887.

8 On the history of Old Belarusian books see: Lastoŭski (1926), Nikalajeŭ (2009). 
Lazutka, Valkonytė and Gudavičius 2004; Lazutka 2007) ${ }^{9}$ brought the GDL into a leading position in Europe with regard to law and legal culture. The Statutes of 1566 were elaborated by taking into account judicial practice and the situation in society. These codes of law, each in its time, became the basis for the regulation of all branches of law in the GDL. ${ }^{10}$

Family law had great importance for the nobility. It regulated property relations, determined the rights and duties of each member of a family. The Statute of the 1529 had two chapters devoted to family law - the 4th and 5th, the same applied to the Statutes of 1566 and 1588, but the numbers of parts were different - the 5th and 6 th. These articles produced serious legal elaboration.

The core point of family law was property. Because of military service and the patriarchal system of inheritance, sons were the main heirs of their father's property. Daughters could receive only a quarter. The mother's property was divided equally between all children. Family law also regulated marriage relations. It paid attention to such aspects as dowries, the groom's and bride's ages, whether the marriage was legal or illegal, and other matters.

There were several norms concerning dowries. A noblewoman had the right to receive movable property from one quarter of her father's property as her inheritance and dowry (Dąbkowski 1916, 22). This part was intended for all daughters and divided between them in equal portions (1529: IV/7). ${ }^{11}$ Similar articles were in the Statutes of 1566 (1566: V/3) and 1588 (1588: V/3). A dowry was an important material aspect of marriage. It gave a certain status to a female in her new family and a guarantee. A dowry belonged to the noblewoman. She had the right to present it to any person. A husband did not have any opportunity to manage his wife's property (Dąbkowski 1916, 99-100), except through her gift list.

A husband assigned a dower (viena and pryvienak) for a dowry. The size of the dower was double the size of the dowry. Legal practice regulated that the dower was assigned on one third of all estates. But the first edition of the Statute of 1529 did not have such an article. It appeared only in the fuller editions of this Statute (Valikonyte 1982, 40). The dower was one of the main conditions of marriage (Czacki 1861, 11,53). An article with more details was inserted into the Statutes of 1566 (1566: V/2) and 1588 (1588: V/2). A female had the right to a dower only in her first marriage. Property with an assigned dower was regarded as pawned property (Dąbkowski 1916,98-99). A husband did not have any right to sell, pledge, or exchange the estate without his wife's permission (Lazutka and Valikonytė 1976,

9 Iabloninskis (1960), von Loewe (1976), Lazutka et al. (2004), Lazutka (2007).

10 Study of the Statutes takes an important place in historiography. Scholars appreciate the Ehrenkreutz (1924; 1935), Bardach (1999), Bershadskii (1893), Maksimeiko (1904), Lappo (1936).

11 The reference to norms of Statute is presented thus: year-1529, chapter-IV and article-7. 
93-95). This condition appeared in the Statute of 1566 (1566: V/16) and stayed in the Statute of 1588 (1588: V/17; Czacki 1861, 55).

According to legislation, only girls needed permission for marriage from parents or guardians. Infringement led to disinheritance and deprivation of a dowry. If guardians placed obstacles in the way of marriage, a noblewoman had the possibility of applying to temporal power (1529: IV/10, 11 (Picheta 1961, 477); 1566: V/7, 8; 1588: V/ 8, 9 (Lappo 1936, 520; Dąbkowski 1916, 26)). At the same time a female had the right to marry voluntarily, without coercion (1529: IV/15; 1566: III/31; 1588: III/39 (Lappo 1911, 519; Taŭstales 2009, 990)).

Marriage of a noblewoman to a person of lower social status (bourgeois or peasant) provoked disinheritance. A female had the right to financial compensation but it was half of what it should have been (1566: V/11 (Spasovich 1890, 154-55; Picheta 1961, 478; Taŭstales 2009, 991, 1001; Andriulis 2003, 59); 1588: V/12). The norm did not allow for the passing of property to representatives of other estates, and limited the possibility of bourgeois and peasants receiving nobility. But this article applied only to women.

If a female entered marriage by violence, she was disinherited (1566: XI/9, 1588: XI/11 (Lappo 1911, 521; Malinovskii 1894, 59). A noblewoman lost her inheritance if she did not want to marry, and she was regarded as a harlot (1566: VIII/ 7; 1588: VIII/ 7).

A dowry should consist of movable property in the case of a female marrying a foreigner and leaving the GDL. The source of this norm was the privilege of 1492. If a noblewoman was an heiress of estates, relatives had the possibility of giving her money instead of property (1529: IV/9) (Spasovich 1890, 153-54; Dąbkowski 1916, 26, 100; Valikonytė 1982, 40; Andriulis 2003, 63).

New articles about dowries were introduced in the Statute of 1588. If daughters received dowries they did not have any right to claim other property after their father's death (1588: V/4) (Czacki 1861, 56).

The Grand Duchy of Lithuania covered a huge territory and its legislation was enforced in all its regions. The three editions of the Statute of Grand Duchy of Lithuania contained the main principles of dowries. But the legal practice was wider and had more conditions than were regulated by common law. It had some special features in the apportionment of a dowry, the content of a dowry, receiving a dowry, and disposal of a dowry.

\section{The Order of Apportionment of a Dowry}

A dowry played an important role in marriage relations. The size of a dower and a female's status in her husband's family depended on it. The custom of 
marrying a girl with a dowry has been known for a long time, but the system of giving a dowry appeared in the sixteenth century. Customary law, legislation, reforms, and judicial practice influenced this process.

Different terms were used to denote dowries in the documents of the fifteenth - sixteenth centuries. Viena (which also meant a dower) was in use in the fifteenth century. It is met in translations of Jahajla's Statute, the Viślicki Statute (AZP, vol. 1, 1846, 17, 39), Zakon Hradski. ${ }^{11}$ Later terms varied according to whom they applied: vyprava ${ }^{12}$ was for parents (the property given to a woman from her own family upon marriage), relatives, and guardians; posah ${ }^{13}$ was for a female (the property received by a woman from her own family); vniesienie for a new family and husband (the property received by a husband from the woman's family). Sometimes in documents posah meant ready money and vyprava was used for movable things, but posah also was possible for both. ${ }^{14}$ We use the term dowry (posah) in this work to mean the property given to a woman from her own family upon her marriage, as her inheritance from her father's property.

The legislation guaranteed a female the right to receive a dowry from her father's estates. Many dower lists presented the realization of norms. A father's duty was to care for all his daughters. For example, Ivan Ivanovič Skorko's debt list to his wife Zofieja Matysovna Gorodeckaja ${ }^{15}$ also presented marriages strategies for his daughters (1584). Nastasja (husband Jan Uglik) and Raina (husband Pavel Rymša) had received dowries. His wife and sons Mihajla, Jurij, Filon, Havrila should give property from their parts to Poloneja, Marychna and Marina. Marina's part was less because she had stolen some of her father's things (NHAB, f. 1755, vop. 1, spr. 10, ark. 84-88). I. Skorko had five daughters and one quarter of his property was to be divided between them. His instructions regarding unmarried girls were necessary in the case of their father's death.

If an estate was passed to other owners, a dowry should be given from it. The court case between Valenty and Andrej Stanislavovič Bilman on the one hand and Matys Mikolajevič Bilman, on the other hand, because their uncle Jan Tumaševič Bilman's estate marked a gift list (1594). In 1574, Jan presented his property to Matys on the condition that he would give a dower to his wife Masuta Jurevna and dowry to his daughter Jadviha (NHAB, f. 1755, vop.1, spr. 13, ark. 236-241 adv).

A dowry was for all daughters, even if one of them decided to go into a convent.

12 The Byzantine code of law.

13 The terms are given in Old Belarusian, the language of the Statutes.

14 See in the following documents: Archiwum Główne Aktów Dawnych (AGAD). AR. Dz. X. Sygn. 49; Nacyjanalny Histaryčny Archiŭ Bielarusi (NHAB) in Hrodna, f. 1664. vop. 1. spr. 316; Liubavskii (1892, 573), Lazutka and Valikonytė (1976, 84-87).

15 Ivan Skorko pawned Zofieja Gorodeckaja one third of his estate Dovgaciški in Hrodna region (paviet) instead of 200 kop of Lithuanian hrošy. 
In the seventeenth century it was a way to avoid unwanted marriage (Sliž 2010, 6299). A dowry was a necessary condition to be accepted into a convent. The property was payment for it (NHAB, f. 694, vop. 1, spr. 463, ark.15). Halška Sebastianovna Toločkovna, a nun of Vilna convent, had the right to one quarter of her father's estate Toločkovskoje Jahelovskoje in the Horodna ${ }^{16}$ region. Her brothers Zachariaš, Flarian, Jakub, and Mateuš were to provide her with this inheritance. Flarian and Mateuš died and so could not do their duty. Halška received money only from Zachariaš. It was 10 kop of Lithuanian hrošy (1640). ${ }^{17}$ Another example was Jan Stefan Slizeń, who gave the abbess of the Basilian convent in Miensk ${ }^{18}$ Hanna Kantakuzen Judita Sliznevna's a dowry in 1695 (NHAB in Hrodna, f. 1663, vop. 1, spr. 89, 107).

If a father did not give a dowry to his daughter during his life, he usually left complete instructions in his will. Noblemen could grant a dowry, but without specifying the quantity of money and goods. So Lavrin Petrovič ordered his sons to apportion dowries for their sisters Justyna and Barbara according to the custom in 1541 (Lietuvos Metrika 1997, kn. 11, 15). Prokop Jakubovič Petelski willed his daughters Katerina and Helena to be brought up to maturity and married off (1626) (NHAB, f. 1755, vop. 1, spr. 31, ark. 114-145 adv).

Some fathers granted concrete sums of money, but it depended on the family's material well-being. The palatine of Mstislavi ${ }^{19}$ Pavel Mikolajevič Pac assigned his daughters Zofieja and Barbara 12,000 zloties each in about 1582 (Wolff 1885, 3637). Dmitrij Ivanovič Olizarovič apportioned his younger daughters Hanna and Barbara 50 kop of Lithuanian hrošy in 1590. His son Fiedor should marry them off (LVIA, f. 525, op. 8, b. 1739, 1.11-13v). Ivan Isakovič Charkovski willed to Fiedora and Bogdana 10 kop of Lithuanian hrošy in 1627 (IJUM 1891, 22, 238-241).

Sometimes testators noted movable goods in their wills. Jan Pietrovič entrusted his wife Zofieja Matysovna with the apportionment of dowries to his daughters. Each of them should receive from two thirds of his estate Ponotera in Koŭna ${ }^{20}$ region, an upper dress (suknia), a velvet hat, a sajan, ${ }^{21}$ a cow, a sheep and a goat (1583; AVAK 1897, vol. 24, 405-406).

Wills show the realisation of legal norms about apportionment of a dowry from a father's estate in the sixteenth - seventeenth centuries. But there was no equality because of the different economic levels of families. Fathers ordered the giving of a

\footnotetext{
16 Today Hrodna, Belarus.

17 The name of the convent is not mentioned in the document. NHAB f. 1755. vop.1. spr. 37. ark. 546 adv-547 adv.

18 Today Minsk, Belarus.

19 Today Mścislaŭl, Belarus.

20 Today Kaunas, Lithuania.

21 Opinions about the word sajan vary. For example, a sajan can be a woman's dress. (Turnau 1999, 160). Another view is that sajan means short upper clothes (Bialiavina 2007, pp. 119-20).
} 
dowry in different ways: without naming a sum of money or with a concrete amount of money and goods; seldom did a will include a list of objects. The father's instructions played an important role in marriage. Relatives or guardians were expected to realise his last wish. Its breach could lead to a court dispute.

Coming of age did not mean that a girl would immediately receive a dowry. Marriage alone would warrant a receipt. So, in 1541 Alžbieta Sakovičovna, the palatine of Vilna Mikolaj Radzivil's wife, demanded from her grandson Jan Janovič Zaberezinski a dowry for her granddaughter Hanna, who was under her guardianship. Aĺžbieta referred to her granddaughter's mature age. Hanna was unmarried and that became a reason to relieve Zaberezinski of his responsibility. Only a future husband could demand a dowry (Lietuvos Metrika 2007, kn. 231, 53, 163.).

A mother, brothers or other relatives, meaning those who used the inheritance, were expected to give a dowry to a female (Liubavskii 1892, 573; Spasovich 1890, 153; Lietuvos Metrika 1997, kn. 224, CXXI.). Judicial decisions supported this idea. Such a decree was made in the case between Ilja Ostožski, the son of the famous hetman of the GDL Konstantin, and his stepmother Aleksandra Sluckaja in 1531. Ilja and his brother Vasil had to apportion a dowry to their sister (Archiwum Książąt Lubartowiczów 1910, t. 3, 385-387).

Mutual agreements between relatives about giving a dowry occurred in noble families. Aĺžbieta Janovna Plateĺskaja ${ }^{22}$ marked in her will in 1583 that she had carried out her first husband's instructions concerning their children. Zofieja married off Jan Jurkovski. She and her husband testified about the receipt of a dowry. Grandmother Helena Kuncovna, Aĺžbieta's mother, brought up granddaughter Helena and gave her movable goods as a dowry. Sons Jan and Pietr noted in a special list that they should marry off their sister Hanna (NHAB, f. 1324, vop. 1, spr. 2, ark. 27-28, 226-226 adv).

If a brother refused to give a dowry, an additional burden fell on other relatives. So Marija Konstantinovna Krošinskaja mentioned in her will in 1569 that her son Fiedor had refused to select a marriage share for his sister Fiedora when she married the grand marshal of the GDL Esif Halecki. The mother had to collect things with the help of her other sons, Ivan and Vasil (NHAB f. 1755, vop. 1, spr. 4, ark. 123124).

If daughters were heirs of estates they could not count on a dowry. Princesses Barbara, Jurij Borovski's wife, and Katerina, Matviej Bogdanovič's wife, initiated a case against their mother Hanna in 1546. The non-granting of a dowry occurred

22 Aĺžbieta Janovna Plateĺskaja married twice. Her first husband was Pietr Timofejevič Puzyna, the second, Auguštyn Čarkovski. 
because their elder sister Hanna was between other claims. In this connection, the noblewomen had received their father Ivan Jurlov's property, and therefore their mother should not give them a dowry: those who kept their father's estates should apportion dowries (Lietuvos Metryka 2008, kn. 30, 130-131). The court relieved Hanna of her responsibilities in the instance.

It was possible to receive a dowry not only from one's father but from other relatives too. The starosta of Mosty, ${ }^{23}$ Alekšy Pokryvnicki, granted 300 kop of Lithuanian hrošy as dowries for his nieces, the daughters of his brothers Jan, Pavel, and Vojtech in 1553 (LVIA, f. 1519, b. 34,1.30). The hetman of the GDL Michail Pac willed to his niece Hanna Herasimovna Pacovna 6,000 zloties in 1682 (Wolff 1885, 112).

The documents contain examples of when noblewomen received immovable property instead of ready money and goods. The horodničy of Vilna, Šymko Mackovič, with the agreement of his wife Zofieja Pavlovna, gave a part of her inheritance to their daughters Hanna and Kachna as a dowry in 1541 (AGAD, AR, dz. I, sygn. 7616; dz. X, sygn. 50).

It took a lot of money for a noble family to marry off a daughter. It might be forced to sell or pawn an estate, to borrow money, or give a dowry in installments. So Barbara Mamoničovna sold half of her estate Povilna in the Vilna province and half her houses in Vilna to Martin Giedrojc for 2, 200 kop of Lithuanian hrošy in 1631. She did not have ready money for a dowry (AVAK 1879, t. 10, 257-263). When Konstantin Konstantinovič Ostrožski did not pay 3,765 zloties from the 15,000 promised to his daughter Halška. He pawned the castle of Rožnov to his son-in-law Jan Kiška in 1570 (LMAB, f. 16-41, 1. 4-5).

If a family did not have the opportunity to give a dowry, it sent the girl for service to a rich family. It was a chance to receive a dowry from patrons. So Lukaš Andrejevič Pomerski mentioned in his dower record that he took his wife Poloneja Litvinovna from the starosta of Zabludov, Stanislav Skaševski's house. She received 43 kop and 12 hrošy in 1598 (NHAB, f. 1755, vop. 1, spr. 15, ark. 321-322 adv).

According to legislation and legal practice, a noblewoman had the right to portion of her father's property even if she decided to take the veil. After her father's death, her mother, brothers, relatives or guardians should give a dowry. The documents testified that a dowry was one quarter of the father's property, but considering a family's financial position, this amount could be less. It was rather expensive to marry off daughters. A family would borrow money, sell or pawn estates. Sometimes a dowry was given in immovable property. The new family expected receive a dowry after the wedding. In certain situations, it could be given later.

23 Today Masty, Belarus. 


\section{Judicial Process Related to a Dowry}

Sometimes relatives, as the main owners of property, used the situation to retain a woman's share. This was a serious reason for initiating a legal case. Before the Statute of 1529, the norms of customary law allowed the support of such complaints, and the decision would be positive for plaintiffs. Based on husbands' appeals (Semen Odincevič and Ivan Duda Polubinski) the court forced Andrej Michajlovič Sanguškovič to give dowries to his sisters Nastasja and Nevindana (Wolff 1895, 437) in 1511. In 1516, Fiedor Michajlovič Podbipiatič was told to give Fiedor Dmitrievič Horski a working estate because of non-payment a dowry (RIB 1903, t. 20, 661, 308, 1142).

Acceptance of the norms of the Statute of 1529 did not mean that the nobility always followed them in practice. The Council of Lords, zemski courts, and courts of palatines heard such cases. For example, Jan Avramovič demanded of his wife's brothers Jan and Stanislav Jurevičes Iljiničes that they give a dowry. The judges decided in his favour in 1530 (Lietuvos Metrika 1997, kn. 224, 384).

Marina Horskaja engaged in legal proceedings with her brother Ivan Ivanavič Horski in 1533. He was supposed to leave her property, but argued that she was not his sister and had married without her parents' permission. These arguments allowed for the disinheritance of Marina, but they were mutually exclusive. Her witnesses, Ivan Andrejevič Polubinski and Vasil Jurevič Polubinski, proved that Marina was a Ivan Horski's daughter. The chancellor of the GDL Oĺbrecht Haštold testified that the noblewoman had been brought up at Grand Princess Helena's, Hanna Hoĺšanska's, Aĺžbieta Haštoĺdovna's, and Zofieja Monvidovna’s courts. Marina had indeed received permission to marry. Taking into account these testimonies, the judges forced Horski to give a dowry (Lietuvos Metrika 1999, kn. 227, 91-93).

After the acceptance of the Statute of 1529, the judicial cases paid attention that a dowry should be apportioned from a quarter of a woman's father's property. Jan Stanislavovič Kovalevič had to give this part to his sister Dorota and her husband Blažej Žyhovski in 1529 (Lietuvos Metrika 1995, kn. 225, 103-104). Similar decisions were made after the introduction of the Statute of 1566. For example, Hrodna zemski court decided in Helena and Hanna Ejsimontovna's favour in 1578 (in this case Helena and Hanna were two sisters and belonged to one family). Their brother Stas should apportion each of them one-eighth shares (NHAB, f. 1755, vop. 1, spr. 7, ark. 292-292 adv). These cases show that noblewomen did not always receive their property after marriage. Relatives sometimes satisfied their claims after cases were decided.

The size of a dowry was to be equal for all daughters. This norm was in use before the Statute of 1529. Katerina Pavlovna Davojnianka, Bogdan Michajlovič Tur Svirski's 
wife, demanded for her sisters Aĺžbieta, Zofieja, and Hanna Krypski an equal dowry. Representatives of the court divided things between sisters (RIB 1903, t. 20,782-783; Tęgowski 2011, 162-63). The norm was included in the Statute of 1529 (1529: IV/7) and used in judicial practice (Lietuvos Metrika 1997, kn. 224, CXX, 295).

It sometimes happened that different sizes of dowry were given to daughters in the same noble family. The archimandrite of Braslaŭ and Hrodna, Klimant Godkinski (earlier his name was Bogdan and he was the chamberlain of Hrodna) and his wife Oksinia Sirkucevna married off their daughter Poloneja to Ezef Stanislavovič Rymand. Her dowry was 60 kop of Lithuanian hrošy and the dower was assigned on one third of the estates at Liada in Lida district and Hlubokoje in Hrodna district, a sum of 60 kop in 1597. Hanna married Filon Hrihirevič Kozlovicki and received the dowry 120 kop. The dower was in that same sum assigned one-third of the estate Kozlovicki in 1597 (NHAB, f. 1755, vop. 1, spr. 15 , ark. 127-130, 175-176 adv). The dowers should be twice as high. Such difference in dowries was unlawful. The size of a dowry could also depend on the financial position of the groom. ${ }^{24}$

In the case of the death of one of the daughters, her dowry was passed through her sisters. It could be a reason to raise an official complaint. In 1501, the horohdniči of Hrodna, Fiedka Havrilovič, demanded for his wife the part of her younger sister Hanna who had died. The mother-in-law should give her the property (Lietuvos Metrika 2007, kn. 6, 260-261).

After the death of a childless woman her dowry returned to her family. This norm was included only in the Statute of 1566 . Before that time it was regulated by customary law. It is rather interesting that in 1542, in the case between Andrej and Jan Jakubovičes Montovtovičes and the palatine of Novogorodok Stanislav Olibrechtovič Gaštoĺd, this norm was regarded as an article of the Statute of 1529 (Lietuvos Metrika 2007, kn. 231, 181). It demonstrates that the custom was so settled and generally accepted that it existed in people's mentality as a norm of law.

Courts used this norm in their decisions. Oĺbrecht Haštoĺd returned his sister Aĺžbieta's dowry from Jan Mikolajevič Radzivil by the court in 1503. She died childless in 1502 . According to her will, all property was to be awarded to her husband. The document did not correspond with custom and was nullified. Radzivil could not confirm his right by any norm of customary law. He appealed to an ecclesiastical court in Rome. It provoked a negative reaction from the judges. They did not want to make a precedent and kept the old norm (Lietuvos Metrika 2007, kn. 6, 297-299; Liubavskii 1892, 574-75).

${ }^{24}$ For example, English aristocratic families married off daughters with different dowries, influenced by the status of the bridegroom (Harris 2002, 50,54). 
But in some other cases a will was a serious reason for leaving a dowry at a husband's house. Maybe international relationships played an important role in the decision. In 1529, the ambassador of the palatine of Valachija (Moldova) Pietr demanded from Fiedor Michajlovič Višnieviecki a dowry that he had kept after his wife's death in about 1523 . There were no children in the family and all property was left for the husband. The Council of Lords supported Višnieviecki (Lietuvos Metrika 1997, kn. 224, CXXII, 312; Wolff 1895, 553-54).

In 1568, Adam Hrigorevič Vlasovič went to law because of his sister Hanna's dowry. She had no children and her husband Jan Mikolajevič Mikloševič should return the property. He had to pay 10 kop but the sum had not been paid in time by 1567 . His debt was doubled (NHAB AB, f. 1755, vop. 1, spr. 4, ark. 285 adv-286 adv).

The documents also contain information about marriage abroad. Property was passed to the nearest relatives and a noblewoman received a dowry in money and goods. For example, in 1516 Jan Stankievič testified that, after marriage, his sister Zofieja Gintovna went to Inflanty ${ }^{25}$ and left him an estate (RIB 1903, t. 20, 1181).

In a case of peculation of a dowry by her husband, a noblewoman had the right to demand compensation from her children. Bazyl Kosak lost a part of his wife Fiedia Michajlovna Haleckaja's property. In 1533 judges deferred the case until her son Pietr came of age. In the future her son and stepson Roman should be paid damages (Bielaruski Archiŭ 1928, t. 2, 117-118; Niesiecki 1841, t. 5, 227).

Sometimes noblewomen used the situation to receive a dowry for a second time. In 1555 the priest of the church of St. Ilja in Pyra (Hrodna region), Ivan, blamed his father-in-law Paška Manojlovič for non-payment of a dowry to his daughter Zinovija and not granting her mother Nastasja's inheritance. But it was revealed in court that that the father had fulfilled his obligations. It was in any case a special document. Manojlovič's archive was stolen, something that was established in the records book. Another argument in support of Manojlovič were that 10 years had passed since his daughter's wedding. The court released him from any further obligation (AVAK 1890, t. 17, 399-401; Vladzimirskii-Budanov 1890, 62).

The next case is rather unusual. Sisters Ludmila and Nastasja Toločinski demanded dowries from their brother Vasil's wife, Marina Bogdanovna Žaslavskaja. They had received their due shares of their father's property. After their brother's death, the sisters initiated cases twice, in 1551 and 1555 (Wolff 1895 , 537-40). At that time Marina married the vice-treasurer of the GDL, Ivan Hornostaj. He played an important role in this case. Ivan wrote a letter to the Grand Duke Žygimont Avgust. Based on family and customary law, he argued that Marina did

${ }^{25}$ For example, rich jewelry is seen in the portraits of Gryzelda Vodynska, Aĺžbieta Zofieja Radzivilovna and others. 
not have to give a dowry to the sisters. The court relieved her of responsibility (AGAD, Archiwum Potockich z Radzynia, sygn. 295, k. 288, 299-304).

The facts mentioned above show that a dowry was often a point at contention. Legislation prescribed clearly to relatives that they should marry off a noblewoman with a dowry, but they did not always want to give up her part of the property. More conflicts were seen with brothers as heirs after their father's death. Usually courts supported women. The decisions make it clear that a dowry should be apportioned from one quarter of an estate. Sometimes, after receiving the property, noblewomen demanded the inheritance again. This was unlawful. A dowry should be equal for all daughters, but in practice it was not so in all families. The property of a childless woman was returned to her family. Judicial practice illustrates that the norms of the Statutes of 1529,1566 , and 1588 were the basis for decisions. Sometimes judges could turn to common law.

\section{List of Movable Property}

At the beginning of the sixteenth century the custom of giving a dowry in movable goods was formed (Lietuvos Metrika 1995, kn. 225, 104.) From this period the practice of writing a list of movable property became wider. Its content was regulated by customary law. No article from the Statutes of 1529, 1566, and 1588 had information about a list of movable property as a document; moreover legislation said nothing about the content of it. There was no fixed proportion between ready money and goods, and between jewellery, clothes, and bed-clothes. Usually a dowry consisted of ready money, movable objects, domestic animals and servants (Lietuvos Metrika 2007, kn. 6, 260-261; Lietuvos Metrika 1995, kn. 225, 247; Lietuvos Metrika 2008, kn. 14, 184-185). According to the legislation, it was unnecessary to record lists of movable property in a record book. This in turn influenced the number of documents that have been preserved to our days.

A list of movable property was among the documents needed for marriage. It was for private use and written in two copies: one copy was for a noblewoman's family, another copy was for a noblewoman's husband.

Customs and traditions influenced the content of a list. It did not have a strict form. The document began with the title. It mentioned the names of the noblewoman and persons who were marrying her off; a date was usually but not always added. Generally the list had the following components: jewellery, clothes, and bed-clothes, but this was not always the case. Sometimes boxes, mirrors, wardrobes and beds were included in the lists. In fact there were many things that a female needed in her everyday life (Popiołek 2003, 216-17). The cost was written near each point and the sum was at the end of a section. A special note was attached 
to things given as presents. Rich families, naturally, had the possibility of giving more expensive things.

The total sum of a dowry was written at the end of the document. Signatures could be placed by persons who marry off a girl, persons who receive a dowry, or witnesses (NHAB in Hrodna, f. 1663, vop. 1, spr. 51, 98; f. 1664, vop. 1, spr. 316, 320; AGAD, AR, dz. X, sygn. 121, k. 23-25; AGAD, AR, dz. XI, sygn. 30; LVIA, f. 525, op. 8, b. 51, 1. 79-80 v; f. 1040, op. 1, b. 187; f. 598, op. 1, b. 1450, 1. 49-50).

It took time and money to collect things for a dowry. Usually the nobility visited such centres of trade as Vilna, Hrodna, Polacak and others, where local and imported articles were sold (Bielaruski Archiŭ 1927, t. 1, 114-122; Kopysskii 1966, 145-94; Bialiavina 2007, 214-15; Barvenava 2008, 116-29, 136-79). For example, the guardian Aleksandr Hilary Polubienski bought for Tereza Šemetovna materials, laces and other articles in Vilna and Warsaw (AGAD, AR, dz. X, sygn. 318, k. 2027). A corset and an apron for Roza Sliznevna were purchased in Vilna (NHAB in Hrodna, f. 1663, vop. 1, spr. 98). A list of movable goods seldom had exact information about place of purchase.

Usually the nobility ordered jewellery, clothes, and beds from local craftsmen. We should note that in the sixteenth - seventeenth centuries craftsmanship had developed to a high level. Belarusian masters could make real works of art (Kopysskii 1966, 96-97). For example, their professionalism was illustrated in prestigious orders in Moscow made by captured prisoners in the war of 1654-67 (Abetsedarskii 1978, 208-53; Russko-Belorusskie sviazi 1972, 62-63, 72-75, 109, 156, 278-79, 290-91, 308-09, 322-24, 328, 345).

Jewellery was imported into the country (Szamek 1988, 92-93, 151-53) but the nobility also turned to local jewellers. Valuable things highlighted the status and wealth of a family. Craftsmen worked in all towns of the GDL such as Vilna, Hrodna, Brest and others (Szamek 1988, 84-85, 92-93, 104-05, 126-27, 150-51; Vitkauskienè 2006, 67-147, 149; Citoŭ 2009, 205-20). Chains, rings, bracelets and other jewellery from the sixteenth - seventeenth centuries have not been saved in great number. It is possible to see them in the collections of the Grand Dukes and their wives (Letkiewicz 2006, 93-97, 212-64). Famous jewellers worked at the courts (Vitkauskienè 2006, 148-200). Women's portraits also illustrate the jewellery of the time. ${ }^{27}$ The nobility also needed other craftsmen from whom they could order clothes, bed-clothes, boxes and beds. But there is no information about makers' names.

${ }^{26}$ For example, rich jewelry is seen in the portraits of Gryzelda Vodynska, Aĺžbieta Zofieja Radzivilovna and others. 
Miscellaneous sources (such as appeals, dower lists) or particularly lists of movable property contain information about lists of objects. In the sixteenth century lists of things were more often contained in the first group. For example, the judicial case between Bohdana Aleksandrovna Kinbutoviča, Januška Pietkovič's wife, and her mother Sviatochna Aleksandrova and her brother Michail mentioned a dowry in 1518: they should give 70 kop of Lithuanian hrošy and things: a fur coat, cloaks, sheepskin coats and a cart (RIB 1903, vol. 20, 1207-1209). This case shows that the goods formed a portion of a dowry.

In a dower list Jan Chrynkievič Osrouh enumerated things from his wife Hanna Rahozianka's dowry in 1562: it consisted of 3 fur coats, 4 measures of cloth, an everyday dress, a silver belt, silver spoons, a pearl collar, a pearl diadem, 2 pearl grid (tkanica), caps, a chemise embroidered in gold, aprons, towels, carpets, bedclothes, a blanket, and 3 servants (NHAB, KMF-18, spr. 260, ark. 555-558). These were typical things for a dowry.

Altogether eleven lists of movable property have been found. This paper presents three of them: below are the dowries of a rich noblewoman, a poor noblewoman, and a nun.

The Radzivils were the richest family in the GDL. They could afford to give good dowries to their daughters. The hetman of the GDL Kryštof Radzivil's daughter Aížbieta married the chancellor of the GDL Leŭ Sapiecha in 1599. Her dowry consisted of 9, 918 kop of Lithuanian hrošy in money and 6,074 kop and 23 hrošy in movable goods. The total sum was 16,000 kop. The list of movable things consisted of very expensive articles. The goldware was luxurious. There were chains, bracelets, jewellery with personal and state coats of arms and other items decorated with rubies, diamonds, emeralds and pearls. Buttons with diamonds and emeralds for head-dresses were noted in the list. There was a sizeable amount of silver goods such as plates, dishes, spoons, and others things. Silk, velvet, satin, and other expensive imported materials were used for sewing clothes, requiring between 16 and 30 cubits for one find piece. The upper clothes were sewn on with sable fur or lynx (AGAD, AR, dz. XI, sygn. 30). This dowry differed from others by its abundant richness. Marriage was a serious matter for the Radzivils. The family presented Aĺžbieta with a dowry in accordance with their status in society.

The next list of movable things belonged to Nastasja Aleksandrovna Adamovičovna. Her uncle Fiedor Adamovič gave her a dowry in the presence of witnesses Roman Adamovič and Mikolaj Cyvinski on 18 May 1614. Nastasja married Kryštof Pietrovič Kolupajlo. ${ }^{27}$ The document was written in the Old Belarusian language. The total sum of things was 17 kop of Lithuanian hrošy and

27 All the persons mentioned lived in the Vaŭkavysk region. 
43 hrošy. There were 16 items in the list. A gilded silver ring was the only piece of jewelry. The clothes (caps, a sheepskin coat, chemises and others) were made of cheap materials (flax, cotton, silk, velvet). ${ }^{28}$ Table-cloths, towers, bed-clothes, an ox, a goat with kids, pigs, and lambs were noted in the document (NHAB in Hrodna, f. 1664, vop. 1, spr. 316). There is a great difference in the items and their respective values found in this list and the previous one.

Judita Sliznevna's dowry requires special attention. She had decided to take holy vows. Her brother Stefan Jan Slizeń gave her a dowry in 1699 that consisted of things necessary for a nun. There were materials for a nun's habits, cloaks, and skirts, a silver spoon, money for a silver cross, religious books, bed-clothes, and other points in the list (NHAB in Hrodna, f. 1663, vop. 1, spr. 89). Items for a nunnery were different from those for a marriage. But a noblewoman received the things that she needed for everyday life in a nunnery.

Lists of movable objects show the different material situations in families. While the documents varied in their contents, but they had the same categories, such as jewellery, clothes, bed-clothes, furniture, domestic animals, and servants.

Lists of movable objects provide a great deal give a lot of information about a woman's property. They describe the jewellery and precious stones used in it. The documents presented a wide spectrum of clothes from outer garments to underwear. They were made of handmade and imported materials, decorated with lace, braid, embroidered in silk, gold, and silver. Headwear (caps, kerchiefs) were mentioned as an essential element of a woman's apparel. A dowry also included bed-clothes, furniture (a bed, mirror and box).

Thus, a noblewoman received the things required for her everyday life in her husband's family. A dowry was the woman's property and she could dispose of it as she wished.

\section{Receipt of a Dowry}

Receipt of a dowry was a private document. It appeared amongst documents concerning marriage relations because of common law and judicial practice. There was not any article in the legislation that demanded a special document from a groom's family about the receipt of a dowry. Like other types of sources, a receipt was required beginning in the second half of the sixteenth century. It was drawn up after assignation and put into a local court book. The document testified to the receipt of a dowry and guaranteed defence against claims from a female or her new family. A list of movable objects and a receipt of having received a dowry

28 This list noted the cheapest kinds of velvet and silk. 
were the first documents signed and attached with a seal by a noblewoman herself or together with her husband. This, however, is not recorded in all sources.

We do have indirect information about the existence of a receipt at the beginning of the sixteenth century. Dorota Gromackaja and her first husband Horski married off her sisters Barbara and Katerina and gave them dowries. The receipts were proof of that fact. But these documents disappeared along with others when Horski was killed. Barbara wanted to exploit the situation and demanded a dowry for the second time. Dorota presented witnesses, who confirmed the assignation. The court decided in Dorota's favour in 1516 (RIB 1903, vol. 20, 297-298).

A husband and a wife, one of the spouses, very rarely the groom's parents, could write receipts. Documents from two spouses are encountered rather often in the sixteenth - seventeenth centuries. Thus, in 1557 Halena Levonovna and her husband testified against her brothers Baltramiej and Jan about the receipt of a dowry and compensation from her mother's property, 200 kop of Lithuanian hrošy in cash and 100 kop in goods (NHAB, KMF-18, spr. 34, ark. 623 adv-624 adv).

After bringing into force the Statutes of 1566 and 1588, and other legal reforms, receipts began to be used widely. For example, in 1570 Mikolaj Tvardovski and his wife Hanna Radzivilovna gave a document about receiving a dowry for the sum of 13, 000 zloties to her father Mikolaj Kryštof Radzivil (AGAD, AR, dz. XI, sygn. 61, k. 11). Two spouses were presented in other documents. Jaroš Nemira and Katerina Lavrinovna Vojnianka in 1591 (NHAB, f. 1785, vop. 1, spr. 12, ark. 2-2 adv), the starosta of Žamojtia Jurij Chodkievič and Zofieja Radzivilovna in 1594 (NHAB, f. 1755, vop. 1, spr. 13, ark. 173-176), Jan Krasnicki and Marina Karasevna in 1599 (NHAB, f. 1755, vop. 1, spr. 16, ark. 8-9 adv) and others all wrote receipts.

A nobleman could himself give a receipt. Maksimiljan Afanasovič Novicki testified that his wife Katerina's brothers Matej, Mikolaj, Vojtech and Pavel Stolinski passed him a dowry in the sum of 3,000 zloties in 1590 (NHAB, f. 1741, vop. 1, spr. 4, ark. 1355-1356). Pavel Vojna gave evidence that his wife Aĺžbieta’s father Mikolaj Sapieha gave him a dowry of 10,000 zloties in 1619 (AGAD, AR, dz. X, sign. 222).

There were documents on behalf of a noblewoman. For example, Katerina Vilčkovna gave a receipt to her mother Marta Jakubovna Kuncevičovna and her brothers, Jan and Heliaš, in 1585. They apportioned the dowry according to her father Oíbrecht Vilček's will. It consisted of 120 kop in money and 100 kop in movable goods (LVIA, f. 1177, op. 1, b. 3191, 1. 49).

It was a rather unusual receipt from a groom's parents. In 1575, Martin Jacynič and Tamila Ivanovna Tyškevičovna testified that their son Mark married Marina who was from Mahdalena Skuminovna Tyškevičovna and Ivan Chreptovič family's, and received a dowry and assigned a dower (NHAB, f. 1737, vop. 1, spr. 2, ark. 77-77 adv). 
Sometimes documents had information that a dowry was apportioned from one quarter of a father's estate. So in 1586 Krystina Andrejevna Bobrovnickaja noted that her brothers Daniel and David gave her a dowry from one quarter of the Žejmenski estate in the $\mathrm{Upita}^{29}$ region and it was $680 \mathrm{kop}$ (AVAK 1899, vol. 26, 224-226).

According to the receipts, we have noblewomen received not only a dowry but also a portion of their mother's or grandmother's property. In 1618, Roman Elski gave his sister Halena and her husband Benedikt Dostojevski a dowry from the estates Sidorenka and Kamenaja Dolina in Hrodna region and money from her mother's estate Volkaŭščyna in Volkovysk region (LVIA, f. 1280, op.1, b. 1439).

In some receipts, the new family renounced other parts of a property and undertook not to claim it in future. In the event of a broken agreement, a certain sum of money that (called zaruka) should be paid. Usually this sum was about equal to the sum of the dowry (AVAK 1907, vol. 32, 241-242).

Receipts for a dowry were widespread in the sixteenth - seventeenth centuries. The document was more important for the family that had married off a noblewoman than for the family receiving the dowry. It had information about both families, the sum of the dowry, estates, the mother's part, the zaruka, the date and place of drawing up the document. But not all the points that have been mentioned were always present in recorded sources, though the document was entered in local court books.

A receipt became an essential legal document in marital relations. It testified to the norms of a dowry. Legislation did not provide for a receipt, but it was needed in legal practice. It was a guarantee of material safety from complaint against a noblewoman, as the document contained evidence of the receipt of a dowry and a disclaimer on other property.

\section{A Noblewoman's Disposal of a Dowry}

A dowry was a female's property. A noblewoman was the only person who had the right to dispose of her dowry. Her husband's permission was unnecessary. A female could devolve, give to a husband or borrow from a dowry (money or objects).

Documents testify that things from a mother's dowry passed to her daughter's dowry by right of succession. The vice-treasurer of the GDL Ivan Hornostaj noted in his will in 1555 that his wife, Helena Vasilevna Solomereckaja, had given a part of her jewellery to her elder daughters, Hanna and Nastasja, who then received the rest after their weddings (AGAD, Archiwum Potockich z Radzynia, sygn. 317, k. 20).

29 Now Upytè in Lithuania. 
According to customary law a childless woman's dowry was returned after her death. A gift list or a notice in a will was necessary for leaving property to a husband. Such dispersions gained legal power bearing from the 1540s and 1550s. In 1554 Hanna Hornostajevna intended her dowry for her husband Bohdan Andrejevič Epimach in the case of her death and a childless marriage (NHAB, KMF-18, spr. 34, ark. 294 adv-297). In another example, a father and relatives had not shown concern for Nastasja Vasilevna Vkolovič during her illness and had not wanted to visit her before her death. For that reason, in 1562 she decided to give her property to her husband Hrigorij Kondratovič Porzvicki (NHAB, KMF-18, spr. 260, ark. $87 \mathrm{adv}-88 \mathrm{adv})$.

Good relations with the husband were an obvious reason for a gift. Settlements had become widespread in the sixteenth - seventeenth centuries. For example, Nastasja Nikiforovna Babajedovna gave her dowry to Bogdan Ivanovič in 1564 (NHAB, KMF-18, spr. 260, ark. 701 adv.), Zofieja Ostafievna Haleckaja to the land scribe of Lida Jan Jurevič Siruc in 1572 (NHAB, f. 1755, vop. 1, spr. 7, ark. 109 adv-111 adv), Hanna Franciškovna Rasievskaja to Jan Zavacki in 1627 (NHAB, f. 1755, vop. 1, spr. 32, ark. 16-17) and there were other cases as well.

Money from a dowry could be borrowed for different purposes. So the starosta of Mścislaví, Ivan Vasilevič Polubenski, noted in his will in 1558 that his wife Raina Koptevna gave 2, 000 kop of Lithuanian hrošy for military service (LMAB, f. 16-74, 1. 83-86v). Raina Koptevna gave 2, 000 kop of Lithuanian hrošy. Money was given in exchange for military service.

The facts mentioned above testify that noblewomen disposed of their property themselves. Children, a husband or other relatives could receive a dowry, but any dispensation should be drawn up legally by means of a gift list or will.

\section{Conclusion}

The sixteenth century was an important period for developing family law. The Statute of 1529 fixed the main tendencies in this branch of law based on common law, privileges and judicial practice. The Statutes of 1566 and 1588 introduced some changes in norms under the influence of common law and judicial practice. Legislation regulated an order for apportionment of dowries. It allowed a noblewoman to dispose of a dowry herself.

Like other norms, customs and norms of law connected to dowries were introduced in the sixteenth century. A dowry was apportioned from one quarter of a father's property, but it was possible to receive a dowry from other persons. It was rather difficult for a family to marry off a female. A dowry consisted of money 
and movable objects such as jewellery, clothes, bed-clothes, and other things. After their father's death, the mother, brothers, relatives or guardians should give a dowry. In the case of refusal to pass over property, a noblewoman could appeal. Usually courts supported such complaints.

The main documents that were customarily utilised a list of movable objects and a receipt for a dowry, and were to have been drawn up at the same period as a dower list. A noblewoman received a dowry whose contents were listed after her wedding. The spouses confirmed it to the bride's parents. After that, a husband wrote a dower list. Any breach of an agreement provoked conflicts and judicial cases.

The facts mentioned above show that common law and judicial practice played an important role in the formation of the law concerning dowries in the GDL. In most cases the nobility followed the articles of the Statute in marriage relations.

\section{References}

\section{Manuscripts}

AGAD - Archiwum Główne Aktów Dawnych, Warsaw

Archiwum Potockich z Radzynia:

sygn. 295.

sygn. 317.

Archiwum Radziwiłłów (AR):

dz. I, sygn. 7616.

dz. X, sign. 49, 50, 121, 222, 318.

dz. XI, sygn. 30, 61 .

Biblioteka Kórnicka, Kórnik

Statut 1566 h., rps. 818, 2710.

Biblioteka Książąt Czartoryskich, Kraków

Statut 1566 g., rps. 1423.

Biblioteka Narodowa, Warsaw

Statut 1566 g., rps. IV. 3075.

LVIA - Lietuvos Valstybès Istorijos Archyvas, Vilnius

f. 525 , op. 8 , b. 51, 1739, 1741 .

f. 598 , op.1, b. 1450 .

f. 1040 , op.1, b. 187 .

f. 1177 , op. 1 , b. 3191 .

f. 1280 , op.1, b. 1439 .

f. 1519 , b. 34 . 
LMAB - Lietuvos mokslų akademijos centrenès bibliotekas Rankraščių skyrius, Vilnius

f. $16-41$.

f. 16-74.

NHAB - Nacyjanaĺny Histaryčny Archiŭ Bielarusi, Minsk, Hrodna

NHAB, KMF-18, spr. 34, 260.

NHAB, F. 694, vop. 1, spr. 463.

NHAB, F. 1324, vop. 1, spr. 2.

NHAB, F. 1737, vop. 1, spr. 2.

NHAB, F. 1741, vop. 1, spr. 1, 4.

NHAB, F. 1755, vop. 1, spr. 4, 7, 10, 13, 15, 16, 31, 32, 37.

NHAB, F. 1785, vop. 1, spr. 12.

NHAB in Hrodna, F. 1663, vop. 1, spr. 51, 89, 98, 107.

NHAB in Hrodna, F. 1664, vop. 1, spr. 316, 320.

\section{Printed material}

Abetsedarskii, Lavrentii, 1978. Belorussiia i Rossiia: ocherki russko-belorusskikh sviazei vtoroi poloviny XVI-XVII v., Minsk: Vysheishaia Shkola.

AIUZ - Akty, otnosiashchiesia $k$ istorii Zapadnoi Rossii, sobrannye i izdannye Arkheographicheskoiu komissieiu (volume 1, 1846; volume 2, 1848), St Petersburg.

Andriulis, Vytautas, 2003, Lietuvos Statutu (1529, 1566, 1588 m.) šeimos teisè, Vilnius: Teisinės Informacijos Centras.

AVAK - Akty, izdavaemye Vilenskoiu komissieiu dlia razbora drevnikh aktov, Vil'na: Tip. Syrkina, 1879, volume 10; 1887, volume 14; 1890, volume 17; 1897 , volume 24; 1899; 1907, volume 32.

Archiwum Komisyi Prawniczej, 1900, volume 7, Kraków.

Archiwum książą Lubartowiczów Sanguszków w Sławucie, 1910, volume 3, Lwów.

Bardach, Juliusz, 1963. 'Świecki charakter zwyczajowego prawa małżeńskiego ludności ruskiej Wielkiego Księstwa Litewskiego (XV-XVII wieku)', Czasopismo Prawno-Historyczne, volume XV, z. I, pp. 85-148.

------, 1988. 'Trzecizna - część swobodna w litewskim prawie majątkowym XVXVI wieku', in idem, O dawnej i niedawniej Litwie, Poznań: Wydawnictwo Naukowe Uniwersytetu im. Adama Mickiewicza w Poznaniu, pp. 120-39.

------, 1989. 'Statuty litewskie jako wyraz kultury prawnej epoki i ich oddziaływanie na kraje sąsiednie’, in Jerzy Kłoczowski (ed.), Między Wschodem a Zachodem, cz. 1: Kultura Umysłowa (Materiały konferencji 1214 VI 1984), Warszawa, pp. 305-38 (Dzieje Lubelszczyzny, volume 6). 
, 1999. Statuty litewskie a prawo rzymskie, Warszawa: OBTA.

Barvenava, Hanna, 2008. Tekstil Siaredniaviečča na ziemliach Bielarusi, Minsk: BDU Kuĺtury i Mastactvaŭ.

Bershadskii, Sergei, 1893. Litovskii Statut i polskie konstitutsii: istorikoiuridicheskoe issledovanie, St Petersburg.

Bialiavina, Valiancina, 2007. Žanočy kaścium na Bielarusi, Minsk: Bielaruś.

Bielaruski Archiŭ, 1927, volume 1. Minsk: Instytut Bielaruskaj Kuĺtury.

Bielaruski Archiŭ, 1928, volume 2. Minsk: Instytut Bielaruskaj Kuĺtury.

Citoŭ, Anatol, 2009. 'Zlatničyja cientry Bielarusi (ad daŭnich časoŭ- da pačatku XX st.)', Archivaryjus, 7, pp. 205-20.

Czacki, Tadeusz, 1861. O litewskich i polskich prawach, o ich duchu, źródłach, zwiazku, $i$ o rzeczach zawartych $w$ pierwszym Statucie dla Litwy, 1529 roku wydanym, volume 2, Kraków.

Dąbkowski, Przemysław, 1916. Dobra rodowe i nabyte w prawe litewskim od XIV do XVI wieku, Lwów: Towarzystwa dla Popierania Nauki Polskiej.

Daniłowicz, Ignacy, 1837. 'Historyczny rzut oka na prawodawstwo litewskie', Pamiętnik Naukowy, 1, 2, pp. 235-67.

------, 1841. 'Vzgliad na litovskoe zakonodatel'stvo i Litovskie Statuty', Iuridicheskie Zapiski, izdavaemye P. Redkinym, 1, pp. 1-46.

1862. Skarbiec diplomatów papiezkich, cesarskich, królewskich, książęcych, volume 2, Wilno.

Derouet, Bernard, 2011, 'Dowry: Sharing Inheritance or Exclusion? Timing, Destination, and Contents of Transmission in Late Medieval and Early Modern France', in Christopher H. Johnson and David Warren Sabean (eds), Sibling Relations and the Transformations of European Kinship, 1300-1900, New York: Berghahn Books.

Dovnar-Zapol'skii, Mitrofan, 1901. Gosudarstvennoe khozaistvo Velikogo kniazhestva litovskogo pri Iagiellonakh, volume 1, Kiev.

Dzierbina, Halina, 1997. Prava i siam'ia epochi Renesansu, Minsk: Technalohija.

Družčyc, Vasil, 2009. 'Mahistrat u bielaruskich miestach z Majdeborskim pravam u XV-XVI staliećciach', ARCHE, 7, pp. 241-337. 
Istoriko-iuridicheskie materialy, izvlechennye iz Aktovykh Knig Gubernii Vitebskoi i Mogiliovskoi, khraniaiashchikhsia v Arkhive v Vitebske (IIOM), 1891.

Ehrenkreutz, Stefan, 1924. 'Stan badań nad Statutami Litewskimi', Ateneum Wileńskie, 7-8, pp. 323-38.

Ehrenkreutz, Stefan (ed.), 1935. Ksiega Pamiatkowa ku Uczczeniu Czterechsetnej Rocznicy Wydania Pierwszego Statutu Litewskiego, Wilno: Towarzystwo Przyjaciół Nauk w Wilnie.

Friedrich, Karin and Barbara M. Pendzich (eds), 2009. Citizenship and Identity in a Multinational Commonwealth: Poland-Lithuania in Context, 1550-1772, Leiden and Boston: Brill.

Frost Robert, 'The Nobility of Poland-Lithuania, 1569-1795', in H.M. Scoot (ed.), The European Nobilities in the Seventeenth and Eighteenth Centuries, volume 2: Northern, Central and Eastern Europe, London and New York: Longman, 1995, pp. 183-222.

Goody, Jack, 1983. The Development of the Family and Marriage in Europe, Cambridge: Cambridge University Press.

Halecki Oskar, 1958. From Florence to Brest (1439-1596), Rome: Sacrum Poloniae Millennium.

Harris, Barbara, 2002. English Aristocratic Women, 1450-1550: Marriage and Family, Property and Careers, Oxford: Oxford University Press.

Iablonskis, K.I. (ed.), 1960. Statut Velikogo Kniazhestva Litovskogo 1529, Minsk.

Kunsmanaite, Jurgita, 2009. Provisions for Widowhood in the Legal Sources of Sixteenth-Century Lithuania. Doctoral Thesis for the Degree of Doctor of Philosophy, Budapest.

Johnson, Christopher H., and Sabean David Warren (eds), 2011. Sibling Relations and the Transformations of European Kinship, 1300-1900, New York: Berghahn Books.

Kopysskii, Zinovii, 1966. Ekonomicheskoe razvitie gorodov Belorusii v XVI- pervoi polovine XVII v., Minsk: Nauka i Tekhnika.

Korpiola, Mia (ed.), 2011. Regional Variations in Matrimonial Law and Custom in Europe, 1150-1600, Leiden and Boston: Brill.

Lappo, Ivan, 1901. Velikoe Kniazhestvo Litovskoe ot zakliucheniia Liublinskoi Unii do smerti Stefana Batoriia (1569-1586), volume 1, St Petersburg. 
, 1936. Litovskii Statut 1588 g., volume 1. Issledovanie, ch. 2, Kaunas.

Lastoŭski, Vaclaŭ, 1926. Historyja bielaruskaj (kryŭskaj) knihi: sproba pajaśnicieĺnaj knihopisi ad kańca X da pačatku XIX stahoddzia, Koŭna: Drukarnia Sakaloŭskaha i Lana.

Lazutka, Stanislavovas and Irena Valikonytè, 1976. 'Imushchestvennoe polozhenie zhenshchiny (materi, zheny, docheri, sestry) privilegirovannogo sosloviia po I Litovskomu Statutu', Nauchnye Trudy Vysshikh Uchebnykh Zavedenii Litovskoi SSR. Istoriia. XVI, 2, pp. 74-102.

Lazutka, Sergei, Irena Valikonytė and E. Gudavičius, E., 2004. Pervyi Litovskii Statut (1529 g.), Vilnius: Margi Raštai.

Lazutka, Stanislavovas, 1982. 'Akademicheskoe izdanie I Litovskogo Statuta', in Pervyi Litovskii Statut 1529 g. Materialy Respublikanskoi nauchnoi konferentsii, posviashchennoi 450-letiiu Pervogo Statuta, Vilnius, pp. 144-52.

------, 2007. Pervyi Litovskii Statut (1529 g.): paleografiia i faksimile rukopisei spiskov Zamoiskikh i Firleiskogo, Vilnius.

Letkiewicz, Ewa, 2006. Klejnoty w Polsce: czasy ostatnich Jagiellonów $i$ Wazów, Lublin: Wydawnictwo Uniwersytetu Marii Curie-Skłodowskiej.

Levickyj, Orest, 1994. 'Sim'ja i pobut Ukrajinciv u XVI st.', in Na perelomi: druha polovyna XVI st., Kyiv, pp. 190-295.

Lietuvos Metrika, 1995. Kn. 225 (1528-1547): 6-oji Teismų knyga, parengè S. Lazutka, I. Valikonytè, Vilnius: Vilniaus universiteto leidykla.

Lietuvos Metrika, 1997. Kn. 11 (1518-1523): Užrašymų knyga 11, parengè A. Dubonis, Vilnius: Mokslo ir enciklopedijų leidybos institutas.

Lietuvos Metrika, 1997. Kn. 224 (1522-1530): 4-oji Teismų knyga, parengè S. Lazutka, I. Valikonytė, Vilnius: Vilniaus universiteto leidykla.

Lietuvos Metrika, 1998. Kn. 25 (1387-1546): Užrašymų knyga 25, parengė D. Antanavičius, A. Baliulis, Vilnius: Mokslo ir enciklopedijų leidybos institutas.

Lietuvos Metrika, 1999. Kn. 227 (1533-1535): 8-oji Teismų knyga, parengè S. Lazutka, I. Valikonytė, Vilnius: Vilniaus universiteto leidykla.

Lietuvos Metrika, 2007. Kn. 6 (1494-1506): Užrašymų Knyga 6, parengè A. Baliulis, Vilnius: Mokslo ir enciklopedijų leidybos institutas.

Lietuvos Metrika, 2007. Kn. 231 (1540-1543): 12-oji Teismų bylų knyga, parengè I. Valikonytė, N. Šlimienè, S. Viskantaitè-Saviščevienė, L. Steponavičienè, Vilnius: 
Vilniaus universiteto leidykla.

Lietuvos Metrika, 2008. Kn. 14 (1524-1529): Užrašymų knyga 14, parengė D. Antanavičius, L. Karalius. Vilnius: Mokslo ir enciklopedijų leidybos institutas.

Liubavskii, Matvei, 1892. Oblastnoe delenie i mestnoe upravlenie LitovskoRusskogo gosudarstva ko vremeni izdaniia pervogo Litovskogo Statuta, Moscow.

Loewe, Karl von (ed. and trans.), 1976. 'Lithuanian Statute of 1529', Studies in East European history, 20, Leiden: Brill.

Maksimeiko, Nikolai, 1904. Russkaia Pravda i Litovsko-Russkoe Pravo, Kiev: Kul'zhenko.

Malinovskii, Ivan, 1894. Uchenie o Prestuplenii po Litovskomu Statutu, Kiev: Tip. Imp. Un-ta cv. Vladimira.

Metryka Vjalikaha Kniastva Litoŭskaha, kn. 30 (1480-1546), 2008, ed. V.S. Mianžynski, Minsk: Belaruskaja Navuka.

Niesiecki, Kasper, 1841. Herbarz Polski, volume 5, Leipzig.

Nikalajeŭ, Mikola, 2009. Historyja bielaruskaj knihi: knižnaja kultura Vialikaha kniastva Litoŭskaha, volume 1, Minsk: Belarus. Encykl. imia P. Broŭki.

Picheta, Vladimir, 1961a. 'Zemel'noe pravo v statutakh 1529 i 1566 g.', in idem, Belorussiia i Litva XV-XVI vv., Moscow: Izd. Akademii nauk SSSR, pp. 473-86.

------, 1961b. 'Litovskii Statut 1529 g. i ego istochniki', in idem, Belorussiia i Litva $X V$-XVI vv., Moscow: Izd. Akademii Nauk SSSR, pp. 503-24.

Pietkiewicz, Krzysztof, 1995. Wielkie księstwo Litewskie pod rzadami Aleksandra Jagellończyka, Poznań: UAM.

Popiołek, Bożena, 2003. Kobiecy świat w czasach Augusta II: studia nad mentalnością kobiet z kręgów szlacheckich, Kraków: Wydawnictwo Naukowe Akademii Pedagogicznej.

RIB - Russkaia Istoricheskaia Biblioteka, 1903, volume 20, Litovskaia Metrika, t.1, St Peterburg: Sepatskaia Tipografiia.

Russko-Belorusskie sviazi vo vtoroi polovine XVII v. (1667-1686 gg.). Sbornik Dokumentov, 1972, Minsk: Izd-vo BGU.

Sabean, David, 1992. 'Social Background to Vetterleswirtschaft: Kinship in Neckarhausen', in Rudolf Vierhaus et al. (eds), Frühe Neuzeit - frühe Moderne? Forschungen zur Vielschichtigkeit historischer Übergangsprozesse, Göttingen: 
Vandenhoeck \& Ruprecht, pp. 113-32.

Šalanda, Aliaksiej, 2009. 'Ziemski sud Haradzienskaha pavieta (1555-1564 hh.)', in A.F. Smaliančuk and N. U. Sliž (eds), 2009. Haradzienski Palimpsiest 2009: Dziaržaŭnyja ŭstanovy i palityčnaje žyčcio XV-XX st., Harodnia, pp. 35-64.

Skitskii, Ivan, 1907. 'Nevenovanye vdovy po Litovskomu Statutu i po tolkovaniiu Senata', Zhurnal Ministerstva Iustitsii, 7, September, pp. 19-64.

Śliž, Natallia, 2007. 'Mižsasloŭny šliub: vypadak z sudovaj spravy 1583 h.', in Aktualnye problemy iz istoricheskogo proshlogo i sovremennosti v obshchestvennogumanitarnykh i sotsio-religiovedcheskikh naukakh Belarusi, blizhnego i dal'nego zarubezh'ia, ch. 2, Vitebsk, pp. 152-53.

------, 2008. 'Vianoŭnyja zapisy ŭ slonimskaj ziemskaj knizie za 1575 h.', in U. Adamuška (ed.), Nacyjanaĺny histaryčny archiŭ Bielarusi: historyja i sučasnasć. Materyjaly jubilein. navuk.-prakt. kanf. pryśviečanaj 70-hoddziu Nac. Hist. Archiva Bielarusi (Minsk, 8 lip. 2008 h.), Minsk, pp. 135-50.

------, 2009. 'Vianoŭnyja zapisy ŭ knizie haradzienskaha ziemskaha suda za 1579 hh.', in A. F. Smaliančuk and Natallia U. Śliž (eds), Haradzienski Palimpsiest 2009: Dziaržaŭnyja ŭstanovy i palityčnaje žyčcio XV-XX st., Harodnia, pp. 65-74.

-----, 2010. “"Niabiesnaja skarbnica...” Vilni', ARCHE, Genius urbis, 3, pp. 6299.

------, 2011. 'Pasahavy rejestr žonki viendenskaha padkamoryja Piatra Kniaževiča', in A. Kavalienia et al. (eds), Ašmianščyna: prabliemy rehijanaĺnaj historyi Bielarusi, Minsk, pp. 220-26.

------, 2012. 'Pieradšliubnaja damova jak krynica pa siamiejna-šliubnych dačynieńniach šliachty VKL XVI-XVII stst.', Uchenye zapiski UO BGU im. P.M. Masherova, Sbornik nauchnykh trudov, volume 13, pp. 17-25.

Spasovich, Vladimir, 1890. 'Ob otnosheniiakh suprugov po imushchestvu po drevnemu polskomu pravu', Sochineniia Spasovicha V.D., volume 3, St Petersburg, pp. 147-160.

Statut Velikogo kniazhestva Litovskogo 1529, 1960, ed. K.I. Jabloninskis, Minsk: Izdatel'stvo Akademii Nauk BSSR.

Statut Vialikaha kniastva Litoŭskaha 1566 hoda, 2003, Minsk: Tesiej.

Statut Velikogo kniazhestva Litovskogo, 1588, Viĺnia: K. Mamonič.

Statut Vialikaha Kniastva Litoŭskaha 1588: teksty, daviednik, kamientaryi, 1989. Minsk: BielSE. 
Strasser, Ulrike, 2004. State of Virginity: Gender, Relation, and Politics in an Early Modern Catholic States, Ann Arbor, MI: University of Michigan Press.

Szamek, Jan, 1988. Polskie złotnictwo, Wrocław \& Warszawa: Ossolineum.

Taŭstales, Aksińnia, 2009. 'Prava siamiejnaje pavodlie litoŭskich statutaŭ', ARCHE, 7, pp. 989-1021.

Tęgowski, Jan, 2011. Rodowód kniaziów Świrskich do końca XVI wieku, Wrocław: WUWR.

Turnau, Irena, 1999. Słownik ubiorów: tkaniny, wyroby pozatkackie, skóry, broń $i$ klejnoty oraz barwy znane w Polsce od średniowiecza do poczatku XIX wieku, Warszawa: Semper.

Vitkauskienè, Birutè, 2006. Złotnictwo wileńskie: ludzi i dzieła, XV-XVIII wiek, Warszawa: Neriton.

Valikonytè, Irena, 1978. Socialno-ekonomicheskoe $i$ pravovoe polozhenie zhenshchin v Velikom Kniazhestve Litovskom (koniec XV-pervaia polovina XVI v.) $i$ ego otrazhenie $v$ Pervom Litovskom statute, Rukopis na soiskanie stepeni kandidata istoricheskikh nauk, Vilnau Universiteto Bibliotekos Rankraščių skyrius, f. 76-2276.

------, 1982. 'I Litovskii Statut - odin iz vazhneishikh istochnikov istorii polozheniia zhenshchin v Velikom kniazhestve Litovskom', in Pervyi Litovskii Statut 1529 g. Materialy Respublikanskoi nauchnoi konferentsii, posviashchennoi 450-letiiu Pervogo Statuta, Vilnius, pp. 38-46.

------, 1997. 'The Venets of Noblewomen in the Grand Duchy of Lithuania', Lithuanian Historical Studies, 2, pp. 97-107.

Vladimirskii-Budanov, Mikhail, 1890. 'Cherty semeinogo prava Zapadnoi Rossii v polovine XVI v.', Chtenie v Istoricheskom obshchestve Nestora Letopistsa, kn. 4, otd. 2, Kiev, pp. 42-78.

Wolff, Józef, 1885. Pacowie: materiały historiko-genealogicznie, St Petersburg: F. Suszczyński.

------, 1895. Kniaziowie litewsko-ruscy od końca czternastego wieku, Warszawa: Gebethner \& Wolff.

Zhemantis, Sergei, 1997. 'Privilei Novogrudskoi Zemle 1440 g.', Rukopisnye pamiatniki: publikatsii i issledovaniia, 4, pp. 415-425. 